\title{
Fluorescent Delta Selective Opioid Peptides from a Cyclic Peptide Combinatorial Library
}

\author{
M. Cazares*, A. Gioseffi*, A. Bunnell*, Y. Li*, and C.T. Dooley*\# \\ *Torrey Pines Institute for Molecular Studies, Port Saint Lucie, FL, 34987, USA \\ \#Brilliant Biosciences, Port Saint Lucie, FL, 34987, USA
}

\section{Introduction}

There has been an increased interest in cyclic peptides as potential therapeutic compounds, largely due to their enhanced binding affinity and specificity to G-coupled receptors when compared to their linear equivalents [1], as well as their increased stability in vivo. Some cyclic peptides of therapeutic value include daptomycin, cyclosporine A, polymyxin, and octreotide.

While clearly of significant value, cyclic peptides may be limited by the difficulty of their synthesis. The ground-state E geometry of the peptide bond limits the peptides from reaching the ring-like conformation that is necessary for cyclization [2]. Additionally, oligomerization often occurs as a side reaction during macrocyclization. These obstacles for synthesis have previously thwarted the development of novel therapeutic macrocycles and prevented the establishment of cyclic peptide-based libraries. Previously, few studies have been reported where cyclic peptide libraries have been used to identify ligands which may be of therapeutic interest [3]. A majority of the cyclic peptide libraries described were constructed by phage display strategies rather than de novo chemical synthesis [4]. Given this, the necessity of a simple synthetic strategy for the synthesis of cyclic peptide libraries is evident.

We have previously described an imidazole-promoted cyclization approach for synthesizing cyclic peptides from their fully unprotected linear peptide thioesters [5]. This method was shown to be highly efficient for the synthesis of cyclic peptides ranging from 5 to 11 amino acid residues. Additionally, this method of imidazole-promoted cyclization minimized the oligomerization side reaction. In our pursuit of new potent ligand tools for opioid receptors, we designed, synthesized, and screened a fluorescent anthraniloyl labeled cyclic peptide library in the positional scanning format using the imidazole-promoted cyclization method.

\section{Results and Discussion}

Boc-amino acids were coupled on the resin by using the PyBOP/DIEA activation method. Glycine was defined at the first position as $\mathrm{R} 1=\mathrm{H}$. $19 \mathrm{~L}-$ and 17 D-amino acids were used as a mixture at the second and fourth positions as R2 and R4. $19 \mathrm{~L}$ amino acids were used as a mixture at the fifth position as R5. A Boc-Dap(Alloc) was incorporated into the linear peptide at the third position. Its side chain was reacted with 2-nitrobenzoic acid to form a resin bound peptide. After being reduced by $\mathrm{SnCl}_{2}$ and treated with anhydrous HF, the linear anthraniloyl fluorescent peptide was cyclized in a mixture solution of $1.5 \mathrm{M}$ aqueous imidazole and acetonitrile (1:7 in volume) at a concentration of $1 \mathrm{mM}$ for $72 \mathrm{~h}$, resulting in the fluorescent cyclic peptide (Scheme 1).

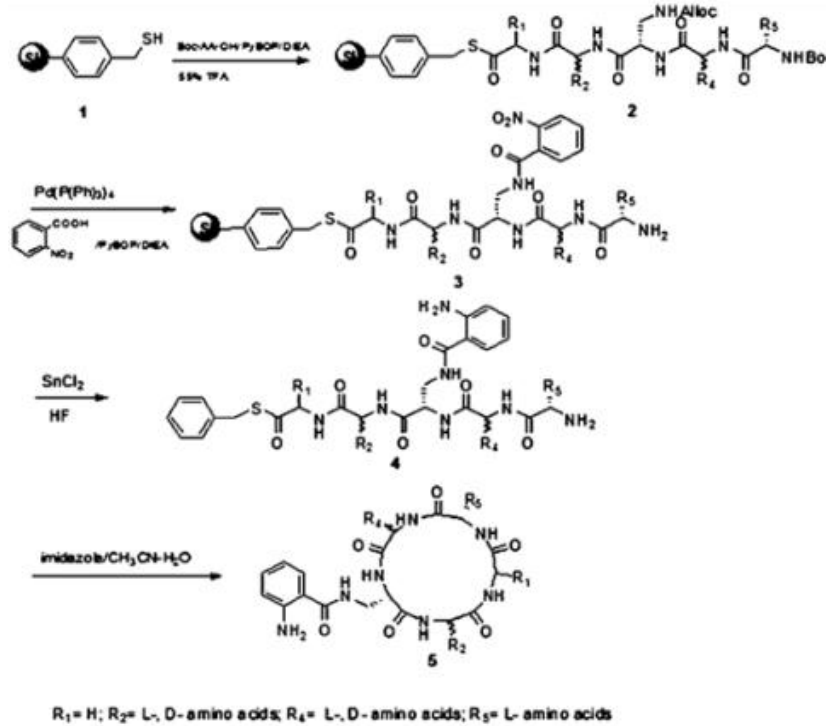

Scheme 1. (1) Boc-AA-OH/PyBOP/DIEA; 55\% TFA. (2) $\mathrm{Pd}\left(\mathrm{PPh}_{3}\right)_{4} / \mathrm{PhSiH}_{3} ; \quad$ 2-nitrobenzoic acid/DIC. $\mathrm{SnCl}_{2} / \mathrm{DMF}$; $55 \% \mathrm{TFA}$. (4) $\mathrm{HF}$ (anhydrous)/anisole, $\mathrm{O}^{\circ} \mathrm{C}$, 2h. (5) 1.5 M imidazole (aq)/acetonitrile $(1: 7 \mathrm{v} / \mathrm{v})$, r.t. $72 \mathrm{~h}$. 
The mixture library was screened at the $\delta$-opioid receptor. Sprague-Dawley rat brains, with cerebellums removed, were homogenized using $50 \mathrm{mM}$ DPDPE buffer, $\mathrm{pH} 7.4$, and centrifuged at $16,500 \mathrm{rpm}$ for 10 min. The pellets were resuspended in fresh buffer and incubated at $37^{\circ} \mathrm{C}$ for $30 \mathrm{~min}$. Following incubation, the suspensions were centrifuged as before, the resulting pellets resuspended in 100 volumes of DPDPE buffer, and the suspensions combined. Membrane suspensions were prepared and used on the same day. Each assay tube contained $0.5 \mathrm{ml}$ of membrane suspension, $2.7 \mathrm{nM}\left[{ }^{3} \mathrm{H}\right]$ DPDPE, $1 \mathrm{mg} / \mathrm{ml}$ compound, and $50 \mathrm{mM}$ DPDPE in a final volume of $0.65 \mathrm{ml}$. The assay tubes were incubated for $2.5 \mathrm{hrs}$ at $25^{\circ} \mathrm{C}$. Unlabeled DPDPE was used as a competitor to generate a standard curve and determine nonspecific binding. The reaction was terminated by filtration through GF-B filters on a Tomtec Harvester 96 (Orange, $\mathrm{CT}$ ). The filters were subsequently washed with $6 \mathrm{ml}$ of $50 \mathrm{mM}$ DPDPE buffer, pH 7.4. Bound radioactivity was counted on a Wallac Betaplate Liquid Scintillation Counter (Piscataway, NJ).

Synthetic Approach to Anthraniloyl (Ant) Labeled Cyclic Penta-Peptide. As described in our previous studies [6], the anthraniloyl group was chosen as our extrinsic fluorescent probe because of its well characterized features, such as a high quantum yield at $415 \mathrm{~nm}$ (excitation at 330nm) for its small size and hydrophilicity, as well as the tendency of its fluorophore to not affect the overall structural characteristics of a peptide or interfere with its biological activity. The synthetic strategy for the anthraniloyl-labeled peptide is illustrated in Scheme 1. The anthraniloyl group is generated by coupling of an $o$-nitrobenzoic acid to an amino group of the peptide, followed by reduction with tin chloride(II). This reduction is mild under near neutral conditions, and is suitable for use with both Boc-and Fmoc-chemistry [7].

Synthesis and Deconvolution of a Positional Scanning Synthetic Combinatorial Library of Anthraniloyl-Labeled Cyclic Peptides. The synthetic strategy described in scheme 1 was applied to the construction of an anthraniloyl-labelled cyclic pentapeptide library in the positional scanning

Table 1. Deconvolution of the most active amino acids derived from the screening data in the delta receptor.

\begin{tabular}{ccccc}
\hline R1 & R2 & R3 & R4 & R5 \\
\hline L-Gly & L-Trp & L-Dap & D-Tyr & L-His \\
& D-Leu & & L-Arg & L-Trp \\
& D-Met & & D-His & \\
& D-Phe & & L-Tyr & \\
& & & L-Trp & \\
\hline
\end{tabular}

$4 \times 5 \times 2=40$
Chart 1. (a) Position 2; (b) 4; (c) 5 in a competitive delta radio receptor binding assay.
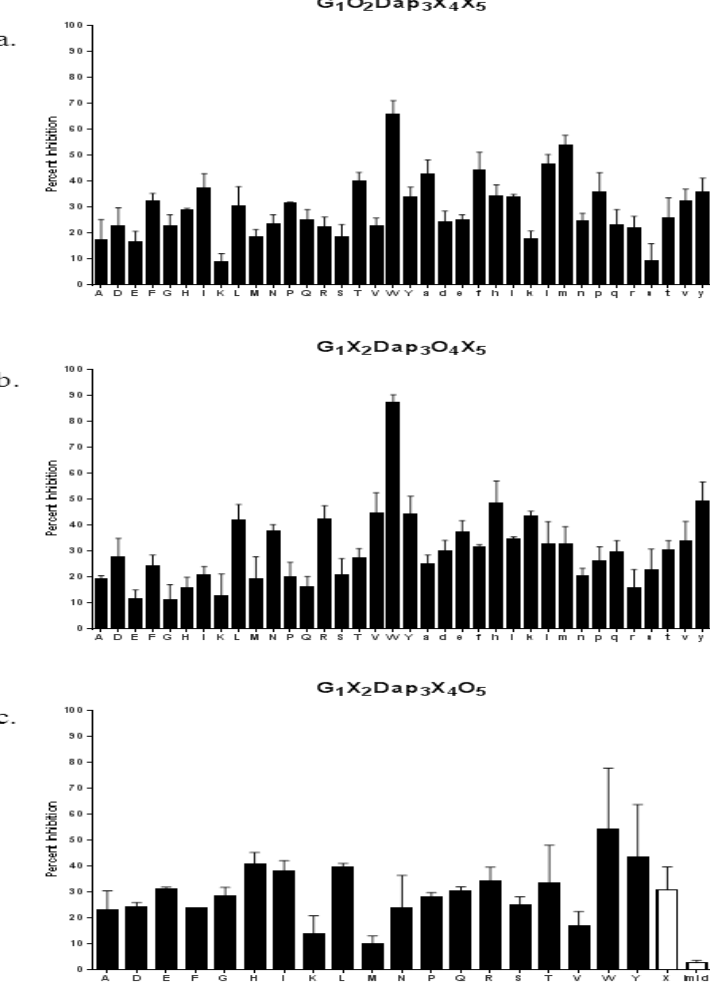
format [8]. Position 1 was fixed with glycine to ensure efficient cyclization [5]. Position 3 was fixed with 2,3-diaminopropionic acid. Its 3 -amino was coupled with the fluorescent anthraniloyl-group. This library was composed of three sublibraries, in which each of the three positions $(2,4$, or 5$)$ were defined with either a single amino acid $(\mathrm{O})$ or a mixture of amino acids (X). For each of the three sublibrary mixtures, the two remaining positions were made up of a mixture of amino acids (X). Positions 2 and 4 contained $36 \mathrm{~L}$ and D- amino acids, while position 5 contained 19 naturally occurring L-amino 
Table 2. Ki Values for the most active (crude) individual compounds from the cyclic peptide library at the delta receptor.

\begin{tabular}{cccccccc}
\hline Peptide \# & R1 & R2 & R3 & R4 & R5 & Ki (nM) & STD \\
\hline 1 & L-Gly & L-Trp & L-Dap & D-Lys & L-Tyr & 11 & 5 \\
2 & L-Gly & D-Phe & L-Dap & D-Lys & L-Tyr & 11 & 6 \\
3 & L-Gly & D-Met & L-Dap & D-Lys & L-Trp & 18 & 6 \\
4 & L-Gly & D.Phe & L-Dap & D-His & L-Tyr & 20 & 4 \\
5 & L-Gly & D-Phe & L-Dap & L-Tyr & L-Trp & 21 & 1 \\
6 & L-Gly & D-Met & L-Dap & L-Tyr & L-Trp & 31 & 8 \\
7 & L-Gly & D-Phe & L-Dap & D-Trp & L-Trp & 33 & 2 \\
8 & L-Gly & D-Met & L-Dap & D-His & L-Trp & 36 & 7 \\
9 & L-Gly & D-Met & L-Dap & D-Tyr & L-Trp & 76 & 2 \\
\hline
\end{tabular}

acids. Thus, this positional scanning library was composed of 91 mixtures. Each mixture contained 684 head-to-tail cyclic pentapeptides at position 2 and 4 and 1296 cyclic pentapeptides at position 5 . In total, this library contains 24,624 individual headto-tail cyclic pentapeptides.

The anthraniloyl-labeled cyclic pentapeptide library was screened in a competitive radio receptor binding assay for the delta opioid receptor. Because of

the abundance of imidazole remaining in each mixture, the effect of imidazole on the delta opioid receptor binding assay was tested prior to screening of the library. This experiment determined that $1 \mathrm{mg} / \mathrm{mL}(14.7 \mathrm{mM})$ imidazole did not have a significant effect in the binding assay. Thus, it was shown that imidazole at this concentration exhibited negligible inhibition.

Each mixture in the library was screened at a concentration of $1 \mathrm{mg} / \mathrm{mL}$. The screening results for the delta selective binding assay are shown in Chart 1 . Several mixtures at each position exhibited percent inhibitions above that of the all $\mathrm{X}$ mixture in which all cyclic peptides are present as a single mixture (all X). One $\mathrm{mg} / \mathrm{mL}$ imidazole was demonstrated not to have a significant effect in the binding assay, exhibiting negligible inhibition.

When a cutoff value of $45 \%$ inhibition was used, the most active amino acids for the mixture making up position 2 were L-Trp, D-Leu, D-Met, and D-Phe; at positon 4 they were D-Tyr, L-Arg, D-His, L-Tyr, and L-Trp; while L-His and L-Trp were the most active at position 5. IC 50 values were not required to differentiate activities in this case because the percent inhibitions observed were on the linear portion of the competition curve (i.e., between 20 and $80 \%$ inhibition).

Individual Peptides from the Cyclic Library. A total of 40 individual peptides were synthesized in parallel by the combination of the most active amino acids identified at the three positions $4 \times 5 \times 2$ (as shown in Table 1). The individual peptides were tested prior to purification in the binding assay for the delta opioid receptor. The results for the most active crude compounds are shown in Table 2.

Table 3. Opioid receptor selectivity.

\begin{tabular}{ccc} 
& DOR $\mathbf{K}_{\mathbf{i}}(\mathbf{n M})$ & MOR $_{\mathbf{i}}(\mathbf{n M})$ \\
\hline Peptide 3 & 18 & 249 \\
Peptide 7 & 33 & $>10,000$ \\
\hline
\end{tabular}

Two individual cyclic peptides, \#3 and \#7, exhibited significant delta receptor activity and were selected for further purification. Following purification, delta and mu opioid receptor binding assays were performed to determine selectivity of the individual peptides (data shown in Table 3).

Determination of the Structure of the Most Active Compound. The HPLC profile of the active purified peptide \#3 actually showed two peaks having an identical mass weight that matched the desired cyclic product. This is caused by the head-to-tail and side chain-to-tail cyclization when $\mathrm{R}^{4}$ is D-Lys (as shown in Scheme 2), as our previous studies have shown that the imidazole-promoted cyclization is not regioselective when Lys is an internal residue.

Scheme 2. Two Possible Isomers of Cyclic Peptide 3 (previously referred to as peptide \#20).

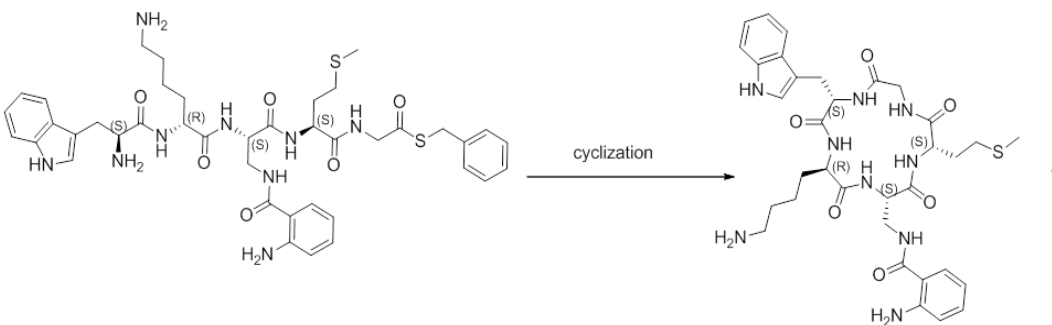

\# 20 linear peptide thioester head-to-tail cyclic peptide

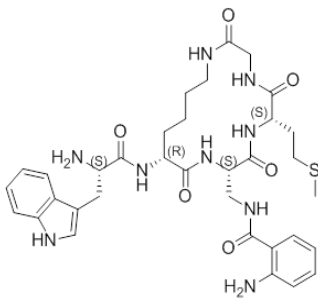

side chain-to-tail cyclic peptide 


\section{Conclusion}

We have identified a cyclic peptide which exhibits delta selective opioid binding. In addition to this selective cyclic peptide, a novel linear peptide of interest (peptide 7) was also synthesized which may prove equally selective and promising (Table 3). Assays are currently being performed to determine the selectivity of these peptides in the kappa opioid receptor as well.

These selective peptides are of great interest for use in FRET assays. While we were unable to purify other cyclized products, the use of these peptides in FRET experiments is still possible regardless of their structure, as the fluorescent tag is exposed in either conformation. The availability of selective opioid peptides with fluorescent tags allows for their use in innovative kinetic and binding studies in situ.

\section{References}

1. (a) Dong, M., Pinon, D.I., Asmann, Y.W., Miller, L.J. Mol. Pharmacol. 70, 206-213 (2006), http://dx.doi.org/10.1124/mol.105.021840; (b) Millward, S.W., Fiacco, S., Austin, R.J., Roberts, R.W. ACS Chem. Biol. 2, 625-634, (2007), http://dx.doi.org/10.1021/cb7001126

2. White, C.J., Yudin, A.K. Nat. Chem. 3, 509-524, (2011), http://dx.doi.org/10.1038/nchem.1062

3. (a) Joo, S.H., Xiao, Q., Ling, Y., Gopishetty, B., Pei, D. J. Am. Chem. Soc. 128, 13000-13009, (2006), http://dx.doi.org/10.1021/ja063722k; (b) Liu, T., Joo, S.H., Voorhees, J.L., Brooks, C.L., Pei, D. Bioorg. Med. Chem. 17, 1026-1033, (2009), http://dx.doi.org/10.1016/j.bmc.2008.01.015; (c) Xiao, Q., Pei, D. J. Med. Chem. 50, 3132-3137, (2007), http://dx.doi.org/10.1021/jm070282e

(d) Xiao, W., Wang, Y., Lau, E.Y., Luo, J., Yao, N., Shi, C., Meza, L., Tseng, H., Maeda, Y., Kumaresan, P., Liu, R., Lightstone, F.C., Takada, Y., Lam, K.S. Mol. Cancer Ther. 9, 2714-2723, (2010),

http://dx.doi.org/10.1158/1535-7163.MCT-10-0308; (e) Fluxa, V.S., Reymond, J.L. Bioorg. Med. Chem. 17, 1018-1025, (2009), http://dx.doi.org/10.1016/j.bmc.2008.01.045; Eichler, J., Lucka, A.W., Pinilla, C.,

Houghten, R.A. Mol. Diversity 1, 233-240, (1995), http://dx.doi.org/10.1007/BF01715527; Eichler, J., Lucka, A.W., Houghten, R.A. Pept. Res. 7, 300-307 (1994).

4. (a) Scott, C.P., Abel-Santos, E., Jones, A.D., Benkovic, S.J. Chem. Biol. 8, 801-815, (2001), http://dx.doi.org/10.1016/S1074-5521(01)00052-7; (b) Meyer, S.C., Gaj, T., Ghosh, I. Chem. Biol. Drug Des. 68, 3-10, (2006) http://dx.doi.org/10.1111/j.1747-0285.2006.00401.x; (c) Bonetto, S., Spadola, L., Buchanan, A.G., Jermutus, L., Lund, J. FASEB J. 23, 575-585, (2009), http://dx.doi.org/ 10.1096/fj.08117069; (d) Kritzer, J.A., Hamamichi, S., Michael McMaffery, J., Santagata, S., Naumann, T.A., Caldwell, K.A., Caldwell, G.A., Lindquist, S. Nat. Chem. Biol. 5, 655-663, (2009), http://dx.doi.org/10.1038/nchembio.193; (e) Kohli, R.M., Walsh, C.T., Burkart, M.D. Nature 418, 658-661, (2002), http://dx.doi.org/ 10.1038/nature00907; (f) Guillen Schlippe, Y.V., Hartman, M.C.T., Josephson, K., Szostak, J.W. J. Am. Chem. Soc. 134, 10469-10477, (2012), http://dx.doi.org/ 10.1021/ja301017y; (g) Kolodziej, A.F., Nair, S.A., Graham, P., McMurry, T.J., Ladner, R.C., Wescott, C., Sexton, D.J., Caravan, P. Bioconjug. Chem. 23, 548-556, (2012), http://dx.doi.org/ 10.1021/bc200613e; (h) Giebel, L.B., Cass, R.T., Milligan, D.L., Young, D.C., Arze, R., Johnson, C.R. Biochemistry 28, 15430-15435, (1995), http://dx.doi.org/ 10.1021/bi00047a006

5. Li, Y., Yongye, A., Giulianotti, M., Martinez-Mayorga, K., Yu, Y., Houghten, R.A. J. Comb. Chem. 11, 1066-1072, (2009), http://dx.doi.org/ 10.1021/cc900100z

6. Li, Y., Dooley, C.T., Misler, J.A., Debevec G., Giulianotti, M.A., Cazares, M.E., Maida, L., Houghten, R.A. ACS Comb. Sci. 14, 673-679, (2012) http://dx.doi.org/ 10.1021/co300110t

7. Isidro-Llobet, A., Álvarez, M., Albericio, F. Tetrahedron. Lett. 46, 7733-7736, (2005), http://dx.doi.org/10.1016/j.tetlet.2005.09.043

8. (a) Houghten, R.A., Pinilla, C., Blondelle, S.E., Appel, J.R., Dooley, C.T., Cuervo, J.H. Nature 354, 8486, (1991), http://dx.doi.org/ 10.1038/354084a0; (b) Dooley, C.T., Chung, N.N., Wilkes, B.C., Schiller, P.W., Bidlack, J. M., Pasternak, G.W., Houghten, R.A. Science 266, 2019-2022, (1994), http://dx.doi.org/ 10.1126/science.7801131; (c) Nazif, T., Bogyo, M. Proc. Natl. Acad. Sci. USA 98, $2967-$ 2972, (2001), http://dx.doi.org/10.1073/pnas.061028898 